\title{
Legal Position of Family Members in the Context of Family Reunion: Albania Case
}

\author{
Ph.D. Cand. Ariana Fullani
}

Doi:10.5901/mjss.2017.v8n3p243

Faculty of Law, Tirana University

\begin{abstract}
Albania has today transposed all directives relating to immigration and asylum presented by the EU and participates in the negotiations about new migration and asylum measures at the regional level. As it is well known, the right to family reunification is a key component of the core principles for respecting family life of migrants. In treating aliens, Albanian legislation does respect the principles of non-discrimination and equality before the law. The aim of this study is to show that Albanian legislation does guarantee the integration and family reunification of foreigners like other countries in the European Union.Actually this institute is regulated by Law No. 108/2013 'On Aliens' adopted on 28 March 2013. The Law is considered to be fully compatible with the EU legislation. Even there are difficulties, in particular to judicial and administrative aspects offamily reunion, the legal position of family members is considered to be similar to the other foreigner in the same conditions. Legal positions of family members, who hold a permanent residence permit or a long term resident's EC residence permits, or a permanent right of residence is stronger than thefamily members in short stay.
\end{abstract}

Keywords: family member, family reunion, migration, short stay, long term resident, permanent residence. Albanian legislation

\section{Introduction}

Albania has a long history of emigration and a very short one of immigration.Migration has been an essential part of Albania's history and extends through the present day, though it has changed both in size and type since $1990^{1}$. However, after the introduction of reforms, the migration picture has evolved in Albania. Albania has opened itself up much more to migrants, though the relative number of immigrants remains low. This opening has included changes in the legislative framework governing immigration and a closer relationship between the Albanian legislation and international conventions governing rights and obligations in the field of migration. Albania has especially changed its legislation to improve alignment with the standards of the European Union for its eventual accession. Albania has today transposed all directives relating to immigration and asylum presented by the EU and participates in the negotiations about new migration and asylum measures at the regional level. Immigration to Albania has been scarce, and the country has not attracted either foreign workers or other immigrants in significant numbers. Even though the situation has changed in recent years, with an increasing immigration from the EU and also third countries, Albania still has only a small foreign population. The marginalized role of immigration is notable in immigration legislation, as this field of law only became sensitive to the requirements posed by democratic legislative procedures and by Albania's international obligations, especially in the field of human rights, during the 1990s. Nowadays Albania has to create incentives for the entry of any foreigner who meets the legal requirements and criteria, in order to become an attractive place for tourists. As it is well known, the right to family reunification is a key component of the core principles for respecting family life of migrants ${ }^{2}$. It is sanctioned in various international instruments protecting human rights ${ }^{3}$.

\footnotetext{
1 See King R, Vullnetari J. Development Research Centre on Migration, Globalisation and Poverty; Brighton, United Kingdom: 2003;Barjaba, K, King, (2005), Introducing and theorising Albanian migration, in King, R., Mai, N. and Schwandner-R. Sievers, S. (eds) The New Albanian Migration. Brighton: Sussex Academic Press, 1-28.

2 For example European Convention of Human Rights (art. 8), The International Convention on the rights of the immigrants and their families of 2003 (art. 44), the Charter of the Fundamental rights in the European Union (art. 7) etc..

3 The most important international agreements with an impact on Albanian immigration legislation include: -International Covenant on Civil and Political Rights of 1966. -International Covenant on Economic, Social and Cultural Rights (1966). -Convention against Torture and other Cruel, Inhuman or Degrading Treatment of Punishment (1984). -Convention on the Rights of Child (1989). -International Convention on the Elimination of All forms of Racial Discrimination (1966). - Convention on the Elimination of All forms of Discrimination against Women (1979). -European Convention on Human Rights (1950). -ILO Forced Labor Convention (1957). -ILO Abolition of Forced Labor Convention (1957). -Convention relating to the status of Refugees (1951) and its Protocol (1967). -Conventions relating to the Status of Stateless Persons (1954) and the Convention on Reduction of Statelessness (1961). -European Social Charter (1961) (1996). European Agreement on Abolition of Visas for Refugees (1959). -European Convention on Extradition (1957). -European Convention on Nationality (1997). -Convention on the Nationality of Married Women (1958).
} 


\section{Legal Framework}

The Albanian Constitution includes strong guarantees for the respect of human rights and fundamental freedoms, not only for Albanians, but for foreigners and stateless persons as well. ${ }^{4}$ In treating aliens, Albanian legislation must respect the principles of non-discrimination and equality before the law. ${ }^{5}$ An alien can be deported only under conditions specified in law and the process must be transparent and respectful of the alien's rights in the Albanian Constitution. Since return to democracy in 1991, different executives have developed migration laws in 1995, 2003, and 2013. The 1995 Migration Act, later modified by the 2003 Labor Migration Act, first regulated migration to Albania. The Act legally defines the government's responsibilities with regard to migration and emigrants: information, assistance, facilitating their integration into the receiving countries' labor market, social and human services systems, and promoting the return of migrants' social, human, and financial capital. The aim was to manage migration flows in order to improve "governability" and control over migrants. It also introduced the idea of immigrant incorporation, respecting the immigrants' culture of origin and not forcing the immigrants to acculturate to Albanian society. Albanian authorities also engage in facilitating the entry, installment into the labor market, legal regulation, and social integration of Albanian emigrants in receiving countries. They have made persistent efforts to negotiate with receiving-country governments and ensure compliance with international conventions on labor and migration ${ }^{6}$.

The integration and family reunification of foreigners granted asylum was firstly regulated by Law No. 9098, dated 03/07/2003 "On the integration and family reunion of foreigners granted asylum in the Republic of Albania". Actually this institute is regulated by Albanian law on immigration No. 108/2013 'On Aliens' adopted on 28 March 2013 as part of its effort to align with EU law. This new Law is fully compatible with: Regulation (EC) No 810/2009 of the European Parliament and of the Council of 13 July 2009 establishing a Community Code on Visas (Visa Code)"7; Directive 2009/52/EC of the European Parliament and of the Council of 18 June 2009 providing for minimum standards on sanctions and measures against employers of illegally staying third-country nationals"8; Council Directive 2009/50/EC of 25 May 2009 on the conditions of entry and residence of third-country nationals for the purposes of highly qualified employment ${ }^{9}$; Directive 2008/115/EC of the European Parliament and of the Council of 16 December 2008 on common standards and procedures in Member States for returning illegally staying third-country nationals ${ }^{10}$; Council Directive 2005/71/EC of 12 October 2005 on a specific procedure for admitting third-country nationals for the purpose of scientific research"11; Council Directive 2004/82/EC of 29 April 2004 on the obligation of carriers to communicate passenger data ${ }^{12}$; Council Directive 2004/81/EC of 29 April 2004 on the residence permit issued to third-country nationals who are victims of trafficking in human beings or who have been the subject of an action to facilitate illegal immigration, who cooperate with the competent authorities"; Council Directive 2004/114/EC of 13 December 2004 on the conditions of admission of thirdcountry nationals for the purposes of studies, pupil exchange, unremunerated training or voluntary service" 13 ; Council Directive 2003/109/EC of 25 November 2003 concerning the status of third-country nationals who are long-term residents ${ }^{14}$; Council Directive 2003/86/EC of 22 September 2003 on the right to family reunification"15;Council Framework

\footnotetext{
${ }^{4}$ See article 16 of the Constitution of the Republic of Albania.

${ }^{5}$ See article 17 of the Const. Article 18: '1. All are equal before the law. 2. No one may be unjustly discriminated against for reasons such as gender, race, religion, ethnicity, language, political, religious or philosophical beliefs, economic condition, education, social status, or ancestry. 3. No one may be discriminated against for reasons mentioned in paragraph 2 if reasonable and objective legal grounds do not exist.'

6In this context, the Albanian government adopted in 2005 the National Strategy on Migration and National Action Plan on Migration, to elucidate priorities for migration. ${ }^{6}$ The Albanian Government adopted this strategy with European Commission funding from the CARDS Program 2001 as well as International Organization for Migration (IOM) technical and co-funding support. This comprehensive migration policy for Albania set a number of priorities: combating irregular migration, encouraging the return and reintegration of migrants, promoting the link between migration and national development, protecting the rights of Albanian immigrants in destination countries, and improving the legislative and institutional framework for migration. However, the effective implementation of these requirements was limited, mainly due to a lack of financial and human resources.
}

${ }^{7}$ CELEX Number 32009R0810, Official Journal of European Union, L Series no. 243, of 15 September 2009, pp 1-58.

${ }^{8}$ CELEX Number 32009L0052, Official Journal of European Union, L Series no. 168, of 30 June 2009, pp 24-32.

${ }^{9}$ CELEX Number 32009L0050, Official Journal of European Union, L Series no. 155, of18 June 2009, pp: 17-29.

${ }^{10}$ CELEX Number 32008L0115, Official Journal of European Union, L Series no. 348, of 24 December 2008, pp 98-107.

${ }^{11}$ CELEX Number 32005L0071, Official Journal of European Union, L Series no. 289, of 3 November 2005, pp 15-22.

${ }^{12}$ CELEX Number 2004L0082, Official Journal of European Union, L Series no. 261, of 6 August 2004, pp 24-27.

${ }^{13}$ CELEX Number 32004L0114, Official Journal of European Union, L Series no. 375, of 23 December 2004, pp 12-18.

${ }^{14}$ CELEX Number 32003L0109, Official Journal of European Union, L Series no. 16, of23 January 2004, pp 44-53.

${ }^{15}$ CELEX Number 32003L0086, Official Journal of European Union, L Series no. 251, of3 October 2003, pp 12-18. 
Decision 2002/946/JHAof 28 November 2002 on the strengthening of the penal framework to prevent the facilitation of unauthorised entry, transit and residence"16; Council Directive 2000/78/EC of 27 November 2000 establishing a general framework for equal treatment in employment and occupation ${ }^{17}$; Directive 96/71/EC of the European Parliament and of the Council of 16 December 1996 concerning the posting of workers in the framework of the provision of services ${ }^{18}$. This law regulates the regime of entry, stay, employment and exit of aliens. The law stipulates the functions and competencies of the State authorities and other entities, be they public or private, Albanian or foreign, carrying out activities in the Republic of Albania which are related to aliens who seek to enter, those who enter, stay and exit from the Republic of Albania. International agreements concluded with the government of other countries, ratified by law, may foresee special and more favourable provisions for the citizens of these countries.

\section{Family Reunion in the Territory of the Republic of Albania}

Family reunification is regulated by article 56 of the Law no 108/2013. It is expressly stated that the alien who has been issued a residence permit in the territory of Albania may lodge an application for family reunification to the Border and Migration Police ${ }^{19}$.The Law on Foreigners adopted in April 2013 in the Republic of Albaniareflected the desire to bring Albanian legislation into accordance with EU standards. The preparation of the new law has required codification of most of the national laws on foreigners and the legal regulations on asylum and migration. The provisions of the new law generally reflect the impact of EU law. It may be said that the principles of international law and human rights have also been taken into consideration, as the Articles affecting the entry, residence and deportation of foreigners, constitutes a manifestation of the principle of non-refoulement ${ }^{20}$. The Law no. 108/2013 date 28.03.2013 regulates issues regarding the status of foreigners almost totally, tending to do so in accordance with "acquiscommunautaire" and superseding the old legislation's dispersed provisions. It regulates the regime of entry, stay, employment and exit of aliens into and from the Republic of Albania. The law stipulates the functions and competencies of the State authorities and other entities, be they public or private, Albanian or foreign, carrying out activities in the Republic of Albania which are related to aliens who seek to enter, those who enter, stay and exit from the Republic of Albania. International Agreements concluded with the government of other countries, ratified by law, may foresee more favorable special provisions for the citizens of these countries, which shall apply with reciprocity. In the area of asylum, the institutional and legal framework has been put in place, and the Law on Asylum is also in line with the EU standards. However there is a greater need to have appropriate human and financial resources in order to enhance implementation of regulatory framework. Problems were mostly related to asylum procedures at reception centers, which have not been always applied in a standardized manner. There

${ }^{16}$ CELEX Number 32002F0946, Official Journal of European Union, L Series no. 328, of5 December 2002.

${ }^{17}$ CELEX Number 32000L0078, Official Journal of European Union, L Series no. 303, of 2 December 2000, pp 16-22.

${ }^{18}$ CELEX Number 31996 L0071, Official Journal of European Union, L Series no18, of 21 January 1997, pp. 1-6.

${ }^{19}$ See article 56 which state that: 1. The alien who has been issued with a residence permit in the Republic of Albania, may lodge an application with the local Border and Migration Police for family reunification purposes, if the following requirements are fulfilled: a) family members of the alien reside outside the territory of the Republic of Albania. In exceptional cases, for humanitarian grounds, according to the criteria approved by decision of the Council of Ministers and procedures approved by Instruction of the Minister of Interior, the application may be lodged when the family member of the alien is in the territory of the Republic of Albania; $b$ ) the alien has been issued with a residence permit in the Republic of Albania for a validity period of at least one year and has the possibility to renew the permit in compliance with the provisions of this law; c) the alien ensures normal accommodation according to the general standards of health and security; c) the alien has sickness insurance covered for him or her and his / her family members for whom he/ she has applied for family reunification; d) the alien has for him/herself and family members sufficient funds to prevent them resorting to social aid scheme; $d$ h) the alien submits the documentation based on the provisions of the decision of the Council of Ministers. 2. The residence permit for family reunification purposes issued for the first time has a validity period of one year and may be renewed, unless otherwise foreseen in agreements or in this law. 3. The residence permit for family reunification purposes, in case of fulfilment of the requirements of this law and the criteria approved by decision of the Council of Ministers shall be renewed according to the provisions of article 38 of this law. 4 . Adult unmarried children and relatives of the direct ascending line of the spouse where they are dependent on them and do not enjoy proper family support in the country of origin or adult unmarried children of the sponsor, who they are objectively unable to provide for their own needs on account of their state of health, may be issued with residence permit in exceptional cases. 5. Unmarried children and also children of the predecessor of the applicant (sponsor) who find it objectively impossible to fulfil their needs because of their health conditions, may be issued with residence permit in exceptional cases. 5. Unmarried children may apply for residence permit for family reunification purposes until they reach 30 years of age, provided that the applicant alien (host) covers the living costs for them. 6 . In case of refusal of issue of the residence permit for family reunification, the alien or the family members have the right to appeal according to the legislation in force.

${ }^{20}$ Bhuiyan J.H., Protection of refugees through the principle of non-refoulement, "An introduction to international law" (ed. by) Islam R., Bhuiyan J.H., Leiden-Boston, 2013, pg. 99-131. 
are difficulties, in particular to judicial aspects, access for asylum seekers to health care, family reunion, social protection, education and housing ${ }^{21}$. It is important to mention here the Decision No 513 of 13 June 2013 "On determining the criteria, procedures and documentation for entry, stay and treatment of aliens in the Republic of Albania" which establish the criteria, procedures and documentation for entry, stay and treatment of aliens in the Republic of Albania, the general criteria to be issued a visa, the main documentation requested from all the categories to be issued with visa etc. and the Directive no. 308 dated 08.05.2009 "On providing citizens with biometric passports", as amended by the Directive no. 394/4 date 11. 11. 2011 on "Procedures for providing the Albanian citizens with biometric passports". It provides a new procedure for providing citizens with biometric passports. According to this procedure "the Albanian citizens who apply for biometric passports must take from the Police Commissariat where they have their residence a form of identification with a picture to fill it in two copies. The form of identification is approved upon the order of the Director General of the State Police. A copy of the form, filled in and verified by the police, is submitted to the employee of the civil status office in the office of application.

\section{Position of Family Members in Event of Short Stay}

A foreigner and members of his family are entitled to enter and reside in Albania for a period not extending three months. In order to be entitled to reside in Albania for a short term, everyone, including each member of a foreigner's family, has to meet individually the conditions for short stay. Accordingly, each family member must hold a passport and a visa unless he or she belongs to one of the categories of individuals who are exempted from the requirements of holding these documents. A foreigner's spouse and his or her children who are under eighteen years of age are, however, not required to hold their own travel documents if their name and date of birth, and with certain exceptions, photography, are included in their family member's passport. In addition to holding the required documents, each person who intends to enter and stay in Albania has to meet the precondition of not constituting jeopardy to public order or security or to public health, and there must not be a valid decision on refusal of entry against her. Furthermore, the family must have sufficient funds to cover the expenses of each family member's residence in Albania and returning to the country of origin. Therefore, the only condition is that the foreigner and any family member must not become an unreasonable burden on the social assistance system of the Republic of Albania.

According to Albanian legislation family members of the alien are the spouse; the partner, which partnership has a stable and proved nature; minors, unmarried children, part of the family composition, including the children under guardianship and children adopted upon a court decision or a directly applicable decision based on the international obligations of the Republic of Albania or a decision which must be recognized in compliance with the international obligations. Family members are, as well, the adult children, unmarried, when they objectively cannot fulfil their needs due to their health situation; direct descendants, under his/her custody or his/her spouse custody, according to the legislation of the country of origin, and who do not enjoy proper family support in their country of origin ${ }^{22}$.

A foreigner's family members who meet the preconditions for short stay are, during their residence in the territory of Albania, entitled to equal treatment as the other foreigners under comparable circumstances ${ }^{23}$.

\section{Position of Family Members in Case of Residence}

A foreigner and members of his family are entitled to reside in Albania if they meet the requirements of the Albanian legislation. The alien, who is the spouse of an Albanian national, shall be issued with a residence permit with a period of validity of no longer than one year when the residence permit is issued for the first time, unless otherwise foreseen in agreements or in this law. The residence permit may be renewed for a validity period of two years. This rule for the spouse of an Albanian national is applicable even to the minor, who is unmarried and under the legal guardianship of the

\footnotetext{
21 See for more at: http://www.qkss.org/repository/docs/Progress_of_Europeanisation_of_the_Security_Sector_in_Albania,_Kosovo_and_ Macedonia_936150.pdf

22 See article 1, par. 14of the Law "On Aliens".

${ }^{23}$ According to the Law "On Aliens" residence as a tourist or for other comparable temporary purposes that lasts for up to three months is considered as a short stay. A foreigner who has entered Albania lawfully, and who meets the general preconditions for entry and residence as defined in the Law "On Aliens", may stay in the country for this period without any administrative formalities such as registering her/his residence or applying for a residence permit. One of the general preconditions for entry and residence that a foreigner must meet to be entitled to stay in Albania for a short term, is possession of a passport or other travel document that is issued by the authorities of the foreigner's country of citizenship or permanent residence, and that is valid throughout her/his entire period of stay in Albania. There are, though, certain exceptions to this requirement.
} 
alien. Obviously, the alien shall not be issued with a residence permit or shall have the residence permit annulled if it is proved that the marriage is of convenience based on the provisions of article 59 of the Law "On Aliens"24. In addition to holding the required documents, each person who intends to stay in Albania has to meet the precondition of not constituting jeopardy to public order or security or to public health, and there must not be a valid decision on refusal of entry against her. Furthermore, the family must have sufficient funds to cover the expenses of each family member's residence in Albania and returning to the country of origin. Therefore, the alien and any family member must not become an unreasonable burden on the social assistance system of the Republic of Albania.

The spouse or partner and the child who has reached majority provided with a residence permit for family reunification purposes, after staying for an uninterrupted period of at least 5 years in the territory of the Republic of Albania based on a residence permit for family reunification purposes and provided that he/she has not been issued with residence permit for reasons other than those of family reunification during this period of stay, have the right to autonomous residence permit. In case of breakdown of the family relationship of the spouse or unmarried partner within this 5 year period from the issue of the first residence permit for family reunification purposes, this right shall be lost. In case of death of the sponsor, the spouse or relatives of the first ascending and descending line, who have resided in the Republic of Albania with a residence permit for family reunification purposes for the validity period of at least 3 years, is legally entitled to apply autonomously for residence permit if they fulfil the general requirements laid down in the Law "On Aliens" and also considering the best interest of the child. If the children who reach the age of majority are issued with permanent residence permit, the first time application for autonomous residence permit shall be made for permanent residence permit. A foreigner's family members who meet the preconditions for the residence are, during their residence in the territory of Albania, entitled to equal treatment as the other foreigners under comparable circumstances.

\section{Position of Family Members of Long Term Residents}

Albanian legislation provides for general rules applicable for the family members of the long term resident ${ }^{25}$. As we mention above, family members of the alien are considered the spouse; partner, which partnership has a stable and proved nature; minors, unmarried children, part of the family composition, including the children under guardianship and children adopted upon a court decision or a directly applicable decision based on the international obligations of the Republic of Albania or a decision which must be recognized in compliance with the international obligations, as well as the adult children, unmarried, when they objectively cannot fulfil their needs due to their health situation; direct descendants, under his/her custody or his/her spouse custody, according to the legislation of the country of origin, and who do not enjoy proper family support in their country of origin. Unmarried partners are to be treated, to the extent

\footnotetext{
${ }^{24}$ According to Albanian legislation "Marriage of convenience" is considered a marriage entered into for the purpose of avoiding the fulfilment of conditions for entry and stay of aliens in the Republic of Albania. Namely a marriage shall be considered to be a marriage of convenience if one of the following circumstances is found: the spouses, after family reunification, do not maintain their marital union based on no reasons at all;b) the spouses after family reunification do not perform their marital obligations; the spouses have never met before the conclusion of marriage; the spouses fail to provide consistent personal data for one-another; the spouses do not speak a language that they both understand; money was exchanged for the conclusion of marriage, unless the money is dowry, and the spouses come from countries where the presentation of dowry is a custom; there is proof of previous marriages of convenience on the part of any of the spouses either in the Republic of Albania or abroad. The alien shall not be issue residence permit for family reunification in case of marriage of convenience. See Canaj E., The right of Family reunification. Albanian and Kosovo cases, in"Human Mobility. Migration from a European and African Viewpoint"edited by Giovanni Carlo Bruno, Immacolata Caruso, Bruno VendittoSoveriaMannelli (CZ), Rubbettino, 2013/SBN 978-88-498-4068-1http://www.issm.cnr.it/pubblicazioni/altre_pubbl/human_mobility/Human_Mobility.pdf; Canaj, E., Family Reunification in Albania. A comparative study in the context of Albaian integration, MJSS, Published by MCSER-CEMAS, Sapienza, Vol.4. nr.6, 2013; Canaj, E., Ildiritto al ricongiungimentofamiliareneldirittointernazionale e dell'UnioneEuropea, EdizioniNuovaCultura, Roma, Italia, 2014.

${ }^{25}$ The conditions on entry and stay of the long-term residents of another country are specified in article 67 of the Law "On Aliens". Namely, the long-term resident of a country, according to the conditions laid down in article 66 of the Law, may enter and stay for 90 days within 180 days in the Republic of Albania without being issued a visa and he / she may apply for residence permit within 60 days from entry if meets the following requirements; a) has a valid travel document and long-term residence permit in the country which is party to an agreement concluded with the Republic of Albania on the mutual movement of long-term residents; b) has the documentation to prove that he/ she has guaranteed normal accommodation in the Republic of Albania;c) provides evidence of stable financial means which are sufficient for his/her and family members; d) has sickness insurance covered in respect of all risks according to the legislation in force; e) has a valid work permit in case of exercise of an economic activity; f) has sufficient financial means to exercise selfemployment activity, in addition to the necessary permit to exercise this activity; g) proves enrolment with an educational or vocational training institution recognized by the Republic of Albania in case of studies or vocational training.
} 
applicable, equally as spouses with respect to family reunification ${ }^{26}$. If the minor who has entered into the Republic of Albania for family reunification purposes, reaches the age of majority, he/she shall have the right to apply independently of the other family members to be issued with residence permit. The alien in case of polygamous marriage has the right to apply for family reunification with only one of the spouses and also the children born by that spouse.

The family members of the alien, who has been issued with residence permit according to the requirements of this article, in order to be issued with residence permit for family reunification, must submit a valid travel document and a copy of the first page of that document; a copy of the residence permit of the sponsor in the Republic of Albania; a certified copy of the family members' long-term residence permit in the country of the previous residence; if necessary, evidence of them being family members of the long-term resident in the other country prior to their arrival to the Republic of Albania; sickness insurance covered in respect of all risks according to the legislation in force and certification of vaccination according to the diseases covered by the calendar of vaccination in Albania; proof of stable financial means sufficient for them without resorting to social assistance system or proof that the long-term resident has sufficient financial resources therefore.

Constituting a serious threat to public order or public security justify cancellation of long-term permits. The grounds for granting resident permits for humanitarian reasons or to victims of human trafficking are related to the termination of the need to grant these permits.

Legal positions of family members, who hold a permanent residence permit or a long term resident's EC residence permits, or a permanent right of residence, is similar to that of the other long term residents.

\section{Conclusions}

Albania has harmonized the legislation with the acquiscommunautaire of the EU. The Albanian legislation on migration introduces six types of residence permit: short term, family, students, long-term, and humanitarian residence permits, as well as those issued to victims of human trafficking. The alien may stay in the Republic of Albania for a short-term period, temporary period and permanent period ${ }^{27}$.Family memberswho enjoy family reunion are the spouse; the partner, which partnership has a stable and proved nature; minors, unmarried children, part of the family composition, including the children under guardianship and children adopted upon a court decision or a directly applicable decision based on the international obligations of the Republic of Albania or a decision which must be recognized in compliance with the international obligations. Family members are, as well, the adult children, unmarried, when they objectively cannot fulfil their needs due to their health situation; direct descendants, under his/her custody or his/her spouse custody, according to the legislation of the country of origin, and who do not enjoy proper family support in their country of origin.Family members of citizens of the EU Member States as well as citizens of USA may stay in Albania for up to three months even without a valid passport. EU and USA citizens must, however, have an official identity card to prove their identity and their right of residence.A foreigner's family members who meet the preconditions for short stay are, during their residence in the territory of Albania, entitled to equal treatment as the other foreigners under comparable circumstances.Legal positions of family members, who hold a permanent residence permit or a long term resident's EC residence permits, or a permanent right of residence, is similar to that of the other long term residents.

\section{References}

Barjaba: "Migration and Ethnicity in Albania: synergies and Interdependencies" Easton Institute for International Studies, Summer Fall 2004, vol. xi, ISSUE 1, page 231-239.

Bërxholi, A.,(2005): Veçoritë e vizualizimit të dinamikës së popullsisë, në: 'Atlasin gjeografik të popullsisë së Shqipërisë (Some particularities of the visualisation of population dynamics, in: Geographic Atlas of the Albanian Population). Akademia e Shkencave, Qendra per Studime Gjeografike (Center for Studies), No.15, pp.156-70.

Barjaba, K. 2000, Contemporary patterns in Albanian migration, South-East Europe

Bhuiyan J.H., Protection of refugees through the principle of non-refoulement, "An introduction to international law" (ed. by) Islam R., Bhuiyan J.H., Leiden-Boston, 2013, pg. 99-131.

Buletini Informativ nr.5, Mbi aktivitetin e Strukturavete M.P.B. gjate muajit shkurt 2014, Ministria e Puneve te Brendshme, 2014, pg.2730.

Buletini Informativ nr.5, Mbi aktivitetin e Strukturavete M.P.B. gjate muajit shkurt 2014, Ministria e Puneve te Brendshme, 2014, pg.26.

C. Brighton: Development Research Center on Migration, Globalisation and Poverty. University of Sussex.

${ }^{26}$ See article 69 paragraph 2 of the Law "On Aliens".

27 See article 32 of the Law "On Aliens". 
Canaj E., The right of Family reunification. Albanian and Kosovo cases, in"Human Mobility. Migration from a European and African Viewpoint"edited by Giovanni Carlo Bruno, Immacolata Caruso, Bruno VendittoSoveriaMannelli (CZ) ,Rubbettino, 2013ISBN 97888-498-4068-1http://www.issm.cnr.it/pubblicazioni/altre_pubbl/human_mobility/Human_Mobility.pdf

Canaj, E., Family Reunification in Albania. A comparative study in the context of Albaian integration, MJSS, Published by MCSERCEMAS, Sapienza, Vol.4. nr.6, 2013

Carletto, C., and Kilic, T. 2009. Moving up the ladder? The impact of migration experience on occupational mobility in Albania, Policy Research Working Paper, n. 4908, The World Bank.

Carletto, C., Davis, B., Stampini, M., Trento, S., and Zezza, A. 2004. Internal mobility and external migration in Albania, ESA Working Paper 04-13, Rome, FAO.

European Union - "Albania Progress Report 2013"

European Union - "Albania Progress Report 2014"

Government of Albania. 2005. National strategy on migration. Tirana: Government of

Guidelines for Integrated Border Management in the Western Balkans http://ec.europa.eu/enlargement/pdf /financial_assistance/cards/publications/ibm_guidelines_en.pdf.http://www.punetejashtme.gov.al/en

Ikonomi, L., E drejtamigratore, Onufri, 2014.

IOM (2004). Analysis of Albanian Immigration and Practise as Compared to EU and International Standards. Gap Analysis on Migration Management in Albania.

King R., "Albanians in Italy and Greece: a study in migration dynamics and social exclusion". Collaborators Sussex Centre for Migration Research, University of Sussex Department of Politics, University of Dundee, 2003, page 1

King, R., and Mai, N. 2008. Out of Albania: From crisis migration to social inclusion in Italy. New York and Oxford: Berghahn.

King, R., and Vullnetari, J. 2003. Migration and development in Albania. Working Paper

King, R., Mai, N., and Schwandner-Sievers, S. eds. 2005. The new Albanian migration. Brighton: Sussex Academic Press.

Kule, D., Mancellari, A., Papapanagos,Nicholson, B. 2004. The tractor, the shop and the filling-station: Work migration as selfhelpdevelopment in Albania, Europe-Asia Studies 56(6): 877-90.

Leka, Agim Albanian migration during the post communist transition and the European integration in global era. An intercultural reflection, Academicus, 2009, p.201-220.

Nicola Mai: "Albanian migration: demographic and other transformations", 2007."Studi migration emigrazione studies", Estratto, centrostudiemigrazione- Roma. Anno xxxv- September 1998- N.131 pages 499-516

Permbledhje e akteve ligjore ne lidhje me perzgjedhjen e te huajve. Per policine e Kufirit dhe Migracionit qe merren me te huajt e parregullt, botimidyte, Ministria e Brendshme, Tirane, 2008.

Piperno, F. 2003. Remittances enhancement for local development in Albania: constraints and opportunities, Working Papers 4/2003, CeSPI, Rome.

Review 3(2): 57-64.

Sokol Dedja The Working of EU Conditionality in the Area of Migration Policy: the Case of Readmission of Irregular Migrants to Albania East European Politics and Societies 2012 26: 115 DOI: 10.1177/0888325410386366

The world fact book Europe: Albania 2009. Washington, DC: Central Intelligence Agency.

Zezza, A., Carletto, G., and Davis, B. 2005. Moving away from poverty: A spatial analysis of poverty and migration in Albania, Journal of Southern Europe and theBalkans 7(2): 175-94. 
ISSN 2039-2117 (online)

ISSN 2039-9340 (print)
Mediterranean Journal of Social Sciences MCSER Publishing, Rome-Italy
Vol 8 No 3

May 2017 